\title{
Disabilities social model: criticism and success $^{1}$
}

\section{Modelo Social de deficiência: crítica e sucesso}

\author{
Rafael de Asís Roig*
}

\section{Abstract}

The philosophy that stands behind a significant number of the regulatory changes underwent by disabilities in the last years is the one duly depicted by the social model of disability. Despite the relevance and appropriateness of the social model approach, when it comes to dealing with disabilities it is not a widely accepted model and it is not without its criticism. The criticism can be divided into two large groups. The first group unfolds from an approach foreign to rights; the second group comes from the inside of the rights discourse. On the other hand, the referents of the social, diversity and identity models, thoroughly discussed in specialized forums and duly embedded in different rules and regulations, have not found yet their application to society. The medical-care approach is mainstream in society. In this paper expose some of the criticisms of the social model and some of the reasons for this limited success

Keywords: Disability. Social model. Human rights.

\section{Resumo}

A filosofia que está por trás de um número significativo de mudanças regulatórias sofridas por deficiência nos últimos anos é a devidamente representada pelo modelo social de deficiência. Apesar da relevância e adequação da abordagem do modelo social, quando se trata de lidar com deficiências não é um modelo amplamente aceito e não é sem a sua crítica. A crítica pode ser dividida em dois

This work collecting part of my reflections gathered in my book Sobre discapacidad y derechos (Dykinson, Madrid 2013).

Catedrático de Filosofía del Derecho. Licenciado en Derecho por la Universidad Complutense de Madrid. Doctor en Derecho por la Universidad Carlos III de Madrid. Ha sido profesor en las Universidades de Castilla La Mancha (Albacete), Complutense de Madrid, Jaén, y Carlos III. Madrid - Espanha. E-mail: rafael.asis@uc3m.es 
grandes grupos. O primeiro grupo desdobra-se de uma abordagem estranha aos direitos; O segundo grupo vem do interior do discurso dos direitos. Por outro lado, os referentes dos modelos sociais, de diversidade e de identidade, amplamente discutidos em fóruns especializados e devidamente inseridos em diferentes normas e regulamentos, ainda não encontraram sua aplicação à sociedade. A abordagem de assistência médica é mainstream na sociedade. Neste artigo expor algumas das críticas ao modelo social e algumas das razões para este sucesso limitado.

Palavras-chave: Incapacidade. Modelo social. Direitos humanos.

\section{Introdução}

In the last years we have witnessed a significant increase in the rules and in the scholarly work on disabilities. In Spain, a number of rules on this matter have been passed, and with regards to the international regulatory arena, in 2006 the International Convention on the Rights of Persons with Disabilities was adopted. This legal text is meant to be a turning point as for how we deal with human rights, and even more so for the rights of persons with disabilities. On the other hand, disabilities have become part of some of the most important contemporary theories of justice. Scholars such as Ronald Dworkin, Amartya Sen or Martha Nussbaum, talk about disabilities in their works.

In addition, this presence of disabilities in the legal and philosophical agenda has gone hand in hand -and has been subsequently supportedby a number of initiatives and associative movements increasingly important in the social sphere.

There is no doubt that all of the foregoing has entailed a significant improvement in the living conditions of the disabled. Notwithstanding, there is still a lot to be done, mainly because the philosophical approach on which a good part of the scholarly literature and the abovementioned rules are rooted, has not yet been followed up by society as a whole. It can even be asserted that it is a controversial approach, frequently 
questioned by the persons with disabilities or by associative movements by which they are represented thereto.

\section{Social model of disability}

The philosophy that stands behind a significant number of the regulatory changes underwent by disabilities in the last years is the one duly depicted by the social model of disability ${ }^{2}$. The easiest way to understand the meaning of this model is to show how it deals with the notions of normalization and discrimination. Hence, contrarily to the approaches that understand disability as a feature derived from individual deficiencies which are to be confronted by means of policies and performances aimed at normalizing those who suffer from them, the social model understands disability as a situation not necessarily stemming from deficiencies but from the social structures and restraints attached to it. The harm caused by disabilities is not a result of deficiencies but of the social outcomes attributed to the first. Consequently, policies and public action shall face these situations normalizing society and taking human rights seriously.

Therefore, the social model can be described in broad terms ${ }^{3}$ by means of the advocacy of the following assumptions:

a) The right way to address disability from a regulatory standpoint is the human rights approach.

b) Disability can be essentially defined as a situation in which people are, or may be, and not an individual feature that characterizes them.

On the impact of the social model see Oliver, M., The Politics of Disablement, Macmillan Press, Hong Kong, 1990; Oliver, M., Understanding Disability. From theory to practice, Palgrave, Malasia, 1996; Barnes, C., Oliver, M. y Barton, L. (eds.), Disability Studies Today, Polity Press, Oxford, 2002.

3 For a deeper characterization, see Palacios, A., El modelo social de la discapacidad, Colección CERMI, Madrid 2008, p. 103 et seq. 
c) In most cases, disability has a social origin. That is the reason why those measures aiming at fulfilling the rights of persons with disabilities shall target society as a whole.

d) Regulatory policies concerning the rights of persons with disabilities must fall within equality and non-discrimination, and moreover, within the generalization of rights.

Hence, the notion of disability proposed by the social model moves away from a concept solely rooted in individual features. It is a notion that has permeated in the International Convention on the Rights of Persons with Disabilities, according to which "disability is an evolving concept and that disability results from the interaction between persons with impairments and attitudinal and environmental barriers that hinders their full and effective participation in society on an equal basis with others." Moreover, always in the words of the Convention, "persons with disabilities include those who have long-term physical, mental, intellectual or sensory impairments which in interaction with various barriers may hinder their full and effective participation in society on an equal basis with others."

Pursuant to the social model, the basic tools for the satisfaction of the rights of the disabled must be based on the two classical dimensions of equality; the negative and the positive differentiation, generalizing and enforcing human rights for this group of people. Therefore, the discussion on the rights of persons with disabilities is predominantly focused on situations and not in identities. The rights of the disabled are, in broad terms, the same to which any person is entitled to, and thus their foundations are grounded neither on individualizing features, nor on the identity of a group.

\section{Criticism on the social model}

Despite the relevance and appropriateness of the social model approach, when it comes to dealing with disabilities it is not a widely accepted model and it is not without its criticism. 
The aforementioned criticism can be divided into two large groups. The first group unfolds from an approach foreign to rights; the second group, on the other hand, comes from the inside of the rights discourse. There are two main arguments within the first group: the care argument and the fear argument. Within the second group I will refer to five stances represented by what it is designated herein as the exception argument, the partial dimension argument, the diversity argument, the identity argument and the covert identity argument.

Notwithstanding, before addressing these points I will disclose another argument which also accounts for criticism on the social model. However, this last point does not fit in any of the latter groups due to its general nature. It can be referred to as the ivory tower argument. The ivory tower argument asserts that the consequences that can be derived from the social model are very hard to implement in practice. It is a point that does not entail any opposition to the premises of the social model but rather to its consequences. From this stance, the social model most certainly has a theoretical value, but theory is one thing and practice is quite another. The theoretical foundations of the social model are correct, but the measures stemming from them are unrealistic, since they do not take into account how societies are or how disabled people actually behave.

However, when facing this argument it must be pointed out how the social model of disability comes from the actual persons with disabilities and from human rights and non-discrimination activists, who, through the advocacy of this model, aim at changing social structures and restraints as well as the way society perceives disability.

It is now time to state the arguments that provide for criticism on the social model. First of all I will address those that are not within the human rights discourse and, moreover, those labelled as care argument and fear argument.

The care argument is based on an understanding of disability that belongs to what in the disability models has been identified as 
the medical or rehabilitation model. ${ }^{4}$ It is in fact an approach that runs parallel to the rights discourse and which has started to be abandoned in the regulatory arena. However, its presence in the social perception of disability is undeniable.

The medical-rehabilitation model of disability, which has its origins in the modern age, starts to be dominant in the 20th century, and particularly so after World War I. Many people were wounded during the Great War and as a result they lost organs or vital functions. They were people that had lost something that society had to give them back. Disability thus started to be regarded as a deficiency which, due to its cause and its possible scope, provided grounds for the implementation of policies aimed at ensuring the provision of social services. This approach on disability increasingly became universal with a dimension that went beyond those who were wounded in World War I.

A number of tools are deemed to be essential with regards to this view of disability: special education, medical rehabilitation, labour quotas, and institutionalized care. Hence, disability becomes an essential part of health care legislation, social care, and social security along with civil legislation.

The care argument, as can be appreciated from the previous paragraphs, deals with a notion of disability that clearly opposes the social model as well as being highly questionable, since it considers disability to be an impairment suffered by some people. In addition, it does not use a rights discourse but a care approach, thus fighting against discimination as it is encountered, or could be encountered, by the disabled, and falls within a weak framework.

The fear argument is somewhat related to the latter, but it shall be considered unique, since it aims at identifying an approach or a position of the disabled persons, their relatives, or their representatives.

On the models of disability, see AA.VV., The New Disability History. American Perspectives, Longmore, P. y Umansky, L. (eds.). New York University Press, Nueva York, 2001. 
Furthermore, it is embedded in the medical-rehabilitation discourse and it is tied to what has been called fear of freedom. In accordance to this argument, achieving greater autonomy as a result of adopting a social model comes along with a decrease of the protection mechanisms projected onto people with disabilities. Access to "normality" of the situations faced by the disabled is thus considered as a risk and a potential disadvantage.

Notwithstanding, the fear argument entails understanding the disabled as inferior beings in need of greater protection and unable to look after themselves. They are people that can be neither autonomous nor independent, and to whom accountability does not apply. Ultimately, the fear argument takes away from the persons with disabilities some of the dimensions traditionally linked to the notion of human dignity and a decent life, dimensions such as the ability of the disabled to make their own choices, decisions, and mistakes.

Within the human rights speech we can find the exception argument, on the basis of which some claims of the social model are rejected. In short it consists in asserting that disability is an exceptional matter and that the rights discourse cannot be built on exceptionalism. It is therefore rooted in a way of understanding rights that highlights the importance of universality. The notion of rights is built on a model of human being aiming for universality, and which can be subsequently modified by exceptional circumstances or situations (among which we can find disability). The construction of a discourse departing from and based on exceptionality, as opposed to being based on universality, is thus rejected.

Even though it is an argument developed from the human rights discourse, it can bring along the removal from this framework of the persons with disabilities. The exception argument does not take into account the fact that being disabled shall not be regarded as an exception. We, as people, are characterized by having different abilities, and being disabled is definitely not an exception. Disability could only be regarded as an exceptional situation if we deal with a close-ended concept of the 
disabled person, and that being the case the exception argument could then bring along discrimination against people with disabilities.

Notwithstanding, sometimes the exception argument shows up within social model approaches. This usually happens when this model brings about the matter of supporting decision-making processes of those people with some sort of intellectual or mental impairment, as well as the rejection of any procedure which entails superseding the will of these people. Therefore, the criticism on this approach consists in stating that there are indeed situations in which replacing the will is the only solution at hand, and that therefore these procedures cannot be rejected outright. It finds its answer in the social model, when the latter asserts that they are exceptional situations and that theories grounded on exceptionality are not to be built. ${ }^{5}$ The use of this argument by the social model shows the application of a "normality" standard, yet much lower than the one applied by other approaches on disability.

Within the human rights discourse, another source of criticism on the social model, which I have labelled as the partial dimension argument, consists in asserting that it is a valid approach for certain kinds of disability situations but that it is not good enough to face others. Moreover, the value of the social model is stated in order to account for physical or sensory disabilities, but at the same time its validity in dealing with intellectual or mental disabilities is questioned. Hence, it is asserted that these kinds of disability shall be understood and are thus characterized by the individual impairments of a given person, thus being the social dimension a relatively unimportant addition. Intellectual or mental disabilities require, above all, healthcare policies and rehabilitation measures.

The partial dimension argument is right when it states the need to combine a rights discourse with a care providing-type discourse when

\footnotetext{
5 From the theoretical arguments of the social model, no exceptional disability situations are addressed. What are actually addressed are exceptional situations of any common person's life, in which what must be analyzed are the possibilities each person might have, but with the limitation of never being able to ground it "on disability" (I thank Agustina Palacios for this nuance).
} 
dealing with disability. Nevertheless, it is wrong when highlighting that the discrimination or differentiation situations faced by the disabled take place because of their personal features and because it is denied that in these instances there is room for a human rights discourse. It is undeniable that there are mental or intellectual disability situations which have a social origin, and that in addition the social perception of these instances is blatantly discriminatory.

As it may have been noted, many of the foregoing arguments share an understanding of disability stemming from the rehabilitation model (although some pretend to be compatible with the rights discourse). Notwithstanding, the social model is also challenged by approaches foreign to that model which are based on identity arguments or on discourses that stress human dignity from genuinely liberal stances. A good example of the first is provided by the discussion within the deaf persons. On the other hand, a good example of the latter is provided by those approaches that advocate for the so called diversity model.

As it is well known, among the claims from deaf people there are two which are especially remarkable due to their broad scope and generality: on the one hand, the right to using and learning sign language; on the other hand, the right to supportive measures to oral communication. Well then, both claims can fall within different philosophical approaches.

Hence, the right to supportive measures to oral communication fits perfectly in the social model discourse. It actually constitutes an attempt to solve a situation of discrimination suffered by some people. This situation is not only due to the individual defining features of those people, but also and above all is a result of how the society structures its communication.

On the contrary, the right to using and learning sign language in many cases is depicted as a demand based on an identity type discourse, and along these lines, it is difficult for it to fit in the longstanding notion of the social model. In some other cases it opposes this notion, giving rise to what can be labelled as the identity model. 
The so-called diversity model, which rises within the Spanish Independent Living Forum ${ }^{6}$ [in Spanish: Foro de Vida Independiente españo/], has served to recover a discourse which, whereas it cannot be considered as identity-based, calls for the value of diversity represented by the people with disabilities; a discourse that has been partially embedded in the International Convention on the Rights of Persons with Disabilities. The existence of disabled people is, in accordance with this model, an example of human diversity, and it constitutes a factor which enriches society as a whole. It is, in any event, a different discourse from the one developed by the Deaf Community, since it is based on community-based parameters, whereas the one proposed by the Independent Living Forum works with liberal parameters. ${ }^{7}$

In the diversity model, "functional diversity is regarded as an indisputable reality which enriches a society made up of people who, lacking any in-depth reflection, do not realize that they too are functionally diverse throughout their lives" (ROMAÑCH, 2009, p. 31). In fact, the diversity model, stressing the social value of persons with disabilities, highlights the right of every person to accomplish a decent human life, or what is the same, the right to achieving their life plans. For that purpose, the persons with disabilities must be autonomous and independent, which entails the removal of barriers either generally by means of the provision of resources, or individually, to allow for every individual to exercise its autonomy (ROMAÑCH; PALACIOS, 2006, p. 28).

For its part, the model advocated by the Deaf Community, the one referred to above as the identity model, also stresses the importance of the disabled, but it does so taking into account that it is a cultural group of

6 This Forum revolves around the principle of "independent living", which is at the same time inspired in the Movement for Independent Living (which was born in the 1960s in the United States). See: DeJong, G., The Movement for Independent Living: Origins, Ideology and Implications for Disability Research, East Lansing: Michigan State University Press, 1979; Shapiro, Joseph, No Pity. People with Disabilities Forging a New Civil Rights Movement, Times Books, Random House, New York, 1994.; García Alonso, J.V. (Coord.), El movimiento de vida independiente. Experiencias Internacionales, Fundación Luis Vives, Madrid, 2003.

7 As for the distinction between liberal and community-based approaches see Pérez de la Fuente, O., La polémica liberal comunitarista. Paisajes después de la batalla, Dykinson, Madrid 2005. 
people with their own values to be safeguarded, ensured and promoted by society. Along these lines, in addition to the removal of barriers, it is necessary to protect the defining features of this group and to draft policies that allow for their development and their continuity. This is why it can be stated that, regardless of the differences between these two models, both criticize the abstract nature of the social model and its little attention paid to diversity as a fact ${ }^{8}$.

In any event, as it is stated above, it is undeniable that the social model itself applies a notion of disability which holds, albeit in minimal doses, certain identity-based implications or, in other words, focuses on individual features. This is precisely what makes up the covert identity argument. This argument asserts that the social model applies a normality standard that can even become discriminatory. It is similar to what can happen with a universal equality model projected onto women or indigenous people, which does not take into consideration their specificity or self-defining identity. This standard of normality is, in the end, an approach on identity which can leave diversity aside ${ }^{9}$.

This is why the social model has to deal with the justification of this understanding of people and, probably, question itself on the use of a universal and abstract model, subsequently becoming open to particular discourses. On the other hand, it is crucial not to overlook that the identity-based stances shall also attempt to build criteria which aim for universality.

This is how it is possible to assert that one of the challenges faced by the understanding of disability from a human rights perspective comes

8 However, within the social model there are those who highlight the need to pay more careful attention to diversity as a fact, and thus call for a more in-depth understanding of identity. See, along these lines, Morris, J., Pride against prejudice. A Personal Politics of Disability, Women's Press Ltd., London, 1991, p. 15 et seq. Also Palacios, A., El modelo social de la discapacidad, p. 182 et seq.

9 The diversity model criticizes the social model for maintaining the discourse's ethical structure while using the notion of abilities. See Romañach, J., Bioética al otro lado del espejo, p. 34 and 35. 
when trying to reconcile these two approaches, when trying to combine the universal and the particular discourse ${ }^{10}$.

In any event it is an ongoing issue when it comes to the human rights discourse. Actually, within this framework, the opposition between universal and particular arguments is a fact that gives rise to present day disputes, for instance, when it comes to reflecting on the concept and foundations of rights or regarding the reflection on the justification -or lack of it whatsoever- of collective rights ${ }^{11}$.

In the field of disabilities this opposition should not be troublesome if the social and the diversity model are jointly understood, but something else may occur, in theoretical terms (as well as in practical terms), if the reference is also the identity model. Actually, the gap between the social and the diversity model lies within two main points. The first one has to do with the allegedly abstract nature of the social model; the second one refers to the notion of human being in this same model. Along these lines, the diversity model shall raise awareness on a very well placed approach and on a perspective which has always been critical of the human being standard.

Nevertheless, problems can be even greater if these two models are dealt with jointly along with the so called identity model. This is due to the fact that this model applies a different approach on the matter, subsequently entailing a different strategy that brings along solutions which are very different from each other or even opposed to each other. For instance, one of those opposing solutions comes up when talking about the kind of education proposed for boys and girls, which is inclusive for the social model and segregated for the identity model. However, from the standpoint of the disability discourse, this is not a relevant

10 See De Asís, R., "Las situaciones de dependencia desde un enfoque de derechos humanos", en Ramiro, M.A. y Cuenca, P. (eds.), Los derechos humanos: la utopía de los excluidos, Debates del Instituto de Derechos Humanos Bartolomé de las Casas, n. 11, Dykinson, Madrid 2010, p. 163 et seq.

11 See Ansuátegui, F.J., Una discusión sobre los derechos colectivos, Debates del Instituto de Derechos Humanos Bartolomé de las Casas, n. 1, Dykinson, Madrid 2001. 
problem if, as pretended by some advocates of the identity model, the deaf person ceases to be considered a disabled person, thus becoming to be considered as a language minority. Notwithstanding, in this point the underlying problem would still be present, i.e., the educational model.

\section{The little success of the social model}

In any event, as I pointed out before, the referents of the social, diversity and identity models, thoroughly discussed in specialized forums and duly embedded in different rules and regulations, have not found yet their application to society. The disabled are still considered as less valid and abnormal, they are deemed to be inferior ${ }^{12}$. Disability is regarded as a true misfortune ${ }^{13}$ and in certain spheres, the presence of persons with disabilities is not even thought of or might be deemed uncomfortable. We are still using derogatory terms to talk about disabilities and we are still building life models, goods, and services that clearly give rise to disability situations.

The medical-care approach is mainstream in society. Persons with disabilities are people marked by having a deficiency which entails a social impairment. This deficiency is often regarded as an illness ${ }^{14}$. Therefore, the treatment of disability shall be targeted to rehabilitate (heal) these people as well as to mitigate the consequences of the given impairment; healthcare and medical assistance become the main referent in the lives of the disabled.

This is still the mainstream approach in many public institutions and within the main social, political and legal actors. The new paradigm has

12 P. Singer points out that mental or intellectual disabilities are abnormal situations conceived as disgraceful. In the words of this scholar, society generally understands that the life of a person with disabilities is not worth as much as the life of a person without disabilities. See Singer, P., Ética práctica, $2^{\mathrm{a}}$ ed., Cambridge University Press, 1995, p. 233.

13 See Dworkin, R., El dominio de la vida, trad. de R. Caracciolo y V. Ferreres, Ariel, Barcelona 1994.

14 Within society there is a misunderstanding when illness and disability are intertwined, same as moral autonomy and physical or functional autonomy are often confused. See Romañach, J., Bioética al otro lado del espejo, cit., p. 30 and 31. 
not yet been followed up by the Administration ${ }^{15}$ nor by the legal actors, particularly so with regards to lawyers and judges. There is attention paid to the situation of the disabled, but looking at how to provide them with special protection, addressed to those who are not capable of making their own decisions. On the other hand, the political arena is somewhat foreign to the matter of disability, not least when a fair share of the persons with disabilities is denied the right to political participation. As a result, the disabled lose interest in those institutions for which public support by means of periodic elections is the main reference for their activity.

Difficulties accessing the labour market or the specialization level with which the disabled enter it, shifts attention from the promotion of their autonomy and takes it to the requirement of protection. Sometimes these difficulties might even bring along a lack of interest on the matter of trade unions.

There are obviously exceptions in every single one of the fields mentioned above. Hence, there are people within the Administration, legal, political or business domains who know, advocate and implement (if applicable), the approach on disability of the social model. Nevertheless, these are not true exceptions.

We could almost consider the thinkers who adopt this approach as exceptions. I pointed out above that disability had become a present topic in the main theories of justice. Nonetheless, the approach on disability does not match the one proclaimed by the social model. For instance, J. Rawls ${ }^{16}$ leaves out of the original situation and of the moral debate a fair share of the persons with disabilities; clearly R. Dworkin ${ }^{17}$ and in a way M. Nussbaum ${ }^{18}$, apply the medical-care approach; For its part A. Sen ${ }^{19}$,

\footnotetext{
15 This is actually corroborated by the fact that any change in the persons within this domain entails going back to the starting point in the discourse concerning the rights of the disabled..

See Rawls, J., El liberalismo político, Crítica, Barcelona 1996, p. 105.

See Dworkin, R., Virtud Soberana, Paidos, Barcelona 2003, p. 309 et seq.

See Nussbaum, M., Las fronteras de la justicia, Paidos, Barcelona 2007, pp. 196 et seq.

See Sen, A., La idea de la justicia, Taurus, Madrid 2010, p. 288 et seq.
} 
has a very negative outlook on disability (although admittedly different from the one developed by P. Singer). The defining features of the social model only appear in scholarly works that directly address disability as the subject matter ${ }^{20}$.

In addition, some of the consequences stemming from the social model are even challenged by persons with disabilities or the associative movements that allegedly represent the interests of the disabled. There is often an excess of protection of the people with disabilities, along with a fear of the consequences of starting the debate on the human rights to which they are entitled. The so-called fear argument lies herein, and is attached to a sort of unintentional seizure of this reflection, which along with a very desirable demand for taking into account persons with disabilities and their associative movements, brings along the rejection of any such approach with origins other than these. This kind of unintentional seizure is also carried out by some specialists in the disability domain, who are reluctant to get into this sphere of reflections promoted from somewhere outside of this "world"; understood as the "world of disability", made up of disabled people, associative movements and all kinds of professionals who are in touch with this reality. What was designated above as the ivory tower argument often refers to those who deal with disability outside of this "world."

Hence, despite the significant advances underwent by the legal domain, Law is unable to alter social stereotypes by itself. In the end, Law is essentially interpretation, so changes in the legal treatment of an issue do not take place only by means of the amendment of certain rules. It is also required to shape the interpreters of the law (every legal actor) in order for them to understand and assimilate the new paradigms. This is also true for those who think that the social model is already embedded in the rules and regulations and that there is no need to amend them.

20 See, for instance Abberley, P., "The concept of oppression and the development of a social theory of disability", Disability, Handicap and Society, vol. 2., n. 1, 1995; Stein, M., "Disability Human Rights", California Law Review, vol. 95, 1, 2007, p. 75 et seq. 
Moreover, it is necessary to combine the legal activity with some other actions. Along these lines, the normalization of society shall be carried out by "naturalizing" disability in education, by regarding disabilities as a reflection of human diversity. But yet again we find ourselves with an understanding of disability foreign to the social model discourse. The demand for inclusive education, in line with the human rights discourse, has been socially challenged and has not found generalized acceptance in education institutions. This was often a result of an issue with the actual rights discourse, which today still turns into the discussion on its scope within private relations. If it is already hard to assume the principle of inclusive education in public schools, it is even harder when it comes to private education, since a new principle arises (private autonomy) which tries to be above those rights. Some other times, the lack of reflection is directly due to the prevailing notion of disability in this domain and which, as I have been reiterating, remains tied to the rehabilitation, care and medical model. In this regard, it is highly remarkable how in education institutions (and particularly at a college level) excellence is opposed either directly or indirectly to disability. This notion of excellence is often based on skills and abilities but remains foreign to the reflection on the possibilities and barriers. Barriers are only taken into account when it comes to physical accessibility, but the most significant and less visible ones remain hidden; those which have to do with social practices, methodologies and stereotypes. Many professors do not take part in this debate and some of them are truly surprised that anybody can relate it to colleges.

The lack of disabilities in college (both with regards to its study and to the presence of disabled people), brings along that the longstanding prevailing vision remains unchanged. Hence, professors who receive a college education normally transfer this notion to their students (who anyhow get to college with this vision) and the same applies to professionals in any of their workplaces. The only way to disrupt this cycle is to take the inclusion of disability in college in a serious manner.

And it has to be done at the same time as disability is opened to society. The ideal "nothing about us without us" shall be extended by 
inserting "with you." As it is well known, this ideal has accompanied the long-running battle over discrimination against persons with disabilities ${ }^{21}$. It is a principle by means of which it is established the need to take into account disabled people when establishing any measure that could affect them. However, there is a way of interpreting this principle that shall be somewhat modified, since it has brought along that the matter of disability is solely unfolded in the environments of the disabled, their families, the associative movements, and hopefully public policies. The reflection on disability is normally performed from movements or people who, in one way or another, have some sort of personal relation with this matter. Nonetheless, disability is something that shall concern us all because it is a situation that affects us all. This is much more evident as we get closer to the rights discourse ${ }^{22}$.

\section{Conclusion}

The rights discourse is not about social assistance ${ }^{23}$. It is about claims and legitimate and duly justified interests which are unwaivable, which are out of any political scheme and above any economic policy. The singularity of the rights approach has been traditionally highlighted with regards to the right to development ${ }^{24}$. In broad terms, this approach comprises, at least: (i) considering the claims or demands as key in order to determine the validity of any public or private policy and as principles that may inspire the latter; (ii) determining who is entitled to the human right enforceable from a legal standpoint; (iii) determining who is liable for the obligations concerning this right (bearers who can be universal

\footnotetext{
21 See Charlton, J. I., Nothing About Us Without Us: Disability Oppression and Empowerment, University of California Press, Berkeley, 1998

22 "Looking at disabilities as a matter of human rights does not only require substantive legal amendments, but also entails a true challenge and calls for an in-depth review regarding moral theories." (CUENCA, 2012, p. 104)

23 This is particularly important in legal systems such as the Spanish legal system, in which social assistance is a legislative competence that can allow for bypassing the human rights discourse.

24 The work by the Office of the United Nations High Commissioner for Refugees titled Preguntas Frecuentes sobre el Enfoque de Derechos Humanos en la Cooperación para el Desarrollo, Nueva York y Ginebra 2006, can be looked at, among others.
} 
or individual and that may not only be limited to public authorities); (iv) demanding legal liability for the non-compliance with the rights in question; and, finally, (vi) demanding the universalization of disability.

Notwithstanding, the entry of disability into the rights discourse also requires amending the latter by means of reviewing some of its longstanding premises in order to include in it those dimensions belonging to what we have designated as social model and diversity model. ${ }^{25}$

\section{Referências}

CUENCA, P. Sobre la inclusión de la discapacidad en la teoría de los derechos humanos. Revista de Estudios Políticos, n. 158, p. 103137, 2012.

ROMAÑACH, J. Bioética al otro lado del espejo. Diversitas: Santiago de Compostela, 2009.

ROMAÑACH, J.; PALACIOS, A. EI modelo de la diversidad.

Diversitas-AIES: Madrid, 2006.

Recebido em: 25/08/2016

Aprovado em: 30/11/2016

25 "In order to solve this problem there is the need for a new way of thinking of citizenship as well as a new analysis of the aims of social cooperation (no longer based on mutual benefit)." Nussbaum, M., Las fronteras de la justicia, cit., p. 22. 